JKM (Jurnal Kebidanan Malahayati),Vol 7,No.4.Oktober 2021,

ISSN (Print) 2476-8944 ISSN (Online) 2579-762X, Hal 785-792

\title{
PENGARUH AROMATERAPI LAVENDER TERHADAP KECEMASAN IBU BERSALIN
}

\author{
Istiqomah Mirazanah ${ }^{1}$, Bunga Tiara Carolin² ${ }^{*}$, Sri Dinengsih ${ }^{3}$ \\ 1,2,3Fakultas Kesehatan Prodi Sarjana Terapan Universitas Nasional Jakarta \\ *korespondensi 2email bunga.tiara@civitas.unas.ac.id
}

\section{ABSTRACT THE EFFECT OF LAVENDER AROMATHERAPY ON MATERNAL ANXIETY}

Background: During the first stage of labor, a woman will experience a psychological disorder, namely anxiety, the impact will cause muscle tension in the body, the birth canal becomes stiff, hard and difficult to expand resulting in the labor process not going smoothly. The main content in lavender oil is linalool acetate which can relax and relax the working system of the nerves and tense muscles.

Objective: This study aims to determine the effect of lavender aromatherapy on maternal anxiety at RSU Kota Tangerang Selatan in 2021.

Methodology: This quasi-experimental study used a pretest and posttest design with a control group design. The sample in this study amounted to 30 mothers who will give birth at RSU Kota Tangerang Selatan with 15 respondents each. The sampling technique used total sampling. The research instrument used the Hamilton Rating Scale for Anxienty (HRS-A) questionnaire. Data were analyzed using the Independent T-test, which previously tested for normality and homogeneity.

Results: The results of the study on anxiety before being given lavender aromatherapy an average of of 22.47 and after being given lavender aromatherapy an average of 18.33 with an average difference of 4.14, in the control group examination I an average of 22.60 and examination II an average 22.27 with an average difference of 0.33 and the effect of lavender aromatherapy on maternal anxiety with a significance level of 0.001 .

Conclusions: There is an effect of lavender aromatherapy on maternal anxiety at RSU Kota Tangerang Selatan in 2021.

Suggestion It is hoped that lavender aromatherapy can be applied as a whole in Indonesian health services.

Keywords: Anxiety, Maternal Lavender Aromatherapy,

\section{ABSTRAK}

Latar Belakang: Persalinan akan menyebabkan gangguan psikologi berupa kecemasan yang dapat mengakibatkan penurunan aliran darah yang membawa oksigen ke rahim dan janin sehingga dapat terjadi halhal yang merugikan bagi ibu dan janin. Salah satu terapi non-farmakologis untuk menurunkan kecemasan adalah melalui pemberian aromaterapi khususnya aromaterapi lavender dapat memberi rasa tenang, sehingga dapat digunakan sebagai manajemen stres.

Tujuan: Penelitian ini bertujuan untuk mengetahui pengaruh aromaterapi lavender terhadap kecemasan ibu bersalin di RSU Kota Tangerang Selatan Tahun 2021.

Metodologi: Penelitian quasi eksperimental ini menggunakan rancangan pretest and posttest with control group design. Sampel dalam penelitian ini berjumlah 30 ibu yang akan melahirkan di RSU Kota Tangerang Selatan dengan masing-masing kelompok 15 responden. Teknik pengambilan sampel menggunakan total sampling. Instrumen penelitian menggunakan kesioner Hamilton Rating Scale for Anxienty (HRS-A). Data dianalisis menggunakan $T$-test Independent yang sebelumnya dilakukan uji normalitas dan homogenitas.

Hasil Penelitian: Hasil penelitian terhadap kecemasan sebelum diberikan aromaterapi lavender rata-rata 22,47 dan sesudah diberikan aromaterapi lavender rata-rata 18,33 dengan selisih rata-rata 4,14, pada kelompok kontrol pemeriksaan I rata-rata 22,60 dan pemeriksaan II rata-rata 22,27 dengan selisih rata-rata 0,33. Terdapat perbedaan rerata skor tingkat kecemasan yang bermakna antara kelompok intervensi dan kelompok kontrol dengan tingkat signifikansi $0,001<0,05$.

Simpulan: Terdapat pengaruh aromaterapi lavender terhadap kecemasan ibu bersalin di RSU Kota Tangerang Selatan Tahun 2021.

Saran Diharapkan pemberian aromaterapi lavender dapat diterapkan secara menyeluruh dipelayanan kesehatan Indonesia.

Kata Kunci : Aromaterapi Lavender, ibu bersalin, kecemasan 


\section{PENDAHULUAN}

Proses kehamilan dan persalinan masih merupakan sesuatu yang berisiko dan dapat mengancam nyawa bagi ibu dan bayi di Indonesia. Menurut World Health Organization (WHO) tahun 2017 sekitar 810 perempuan (\%) meninggal setiap harinya akibat komplikasi kehamilan dan proses kelahiran. Sekitar $94 \%$ dari semua kematian ibu terjadi di negara berpenghasilan rendah dan menengah, dimana $75 \%$ dari penyebab semua kematian ibu akibat komplikasi utama yaitu, perdarahan hebat, infeksi, tekanan darah tinggi selama kehamilan, komplikasi dari persalinan dan aborsi yang tidak aman (WHO, 2019).

Melihat fenomena tersebut, menjadikan masa persalinan merupakan salah satu tahapan yang mendebarkan bagi setiap wanita (Kasdu, 2015). Pada kala I, seorang ibu dapat mengalami gangguan kecemasan dibandingkan kala II dimana seorang ibu dapat mengontrol dirinya kembali, pada kala III seorang ibu juga merasakan penurunan rasa nyeri dan perasaan lelah dibandingkan perasaan cemas, selanjutnya kala IV seorang ibu akan berfokus pada tanggung jawab barunya untuk mengasuh dan merawat bayi.

Menurut Nolan (2018) selama persalinan kala I, seorang wanita akan mengalami gangguan psikologi yaitu kecemasan. Kecemasan merupakan reaksi fisik, mental, kimiawi dari tubuh terhadap situasi yang menakutkan, mengejutkan, membingungkan, membahayakan dan merisaukan seseorang (Yosep, 2017). Berdasarkan penelitian Lamadah dan Nomani (2016) yang dilakukan di departemen tenaga kerja di Rumah Sakit Universitas Bersalin El-Shatby di Alexandria, Mesir ditemukan $82 \%$ ibu dalam masa persalinan mengalami gangguan kecemasan. Sementara itu di Indonesia yang dilakukan Aisyah, et al (2019) dalam penelitiannya yang dilakukan di Bandung ditemukan $73,3 \%$ responden mengalami kecemasna sedang, bahkan ditemukan juga $20 \%$ mengalami kecemasan berat dan hanya $6,7 \%$ yang mengalami kecemasan ringan. Adapun penelitian lainnya yang dilaksanakan di Kabupaten Tangerang yang merupakan wilayah Provinsi Banten yang dilakukan oleh Syukrini (2016) didapatkan 46,7\% mengalami kecemasan sedang, sisanya berada pada kategori berat dan ringan sebanyak $26,7 \%$.

Selain itu Simpkin (2015) menjelaskan bahwa faktor psikologis juga berhubungan dengan kecemasan selama persalinan kala I yaitu beberapa ketakutan melahirkan diantaranya yaitu takut akan peningkatan nyeri, takut akan kerusakan atau kelainan bentuk tubuhnya seperti episiotomi, rupture, jahitan ataupun seksio sesarea, serta ibu takut akan melukai bayinya. Faktor psikis dalam persalinan merupakan faktor yang sangat penting mempengaruhi lancar tidaknya proses kelahiran. Menurut Stuart (2016) faktor fisiologis penyebab kecemasan yaitu terjadinya perubahan fisik yang dialami ibu. Perubahan tersebut yaitu perubahan kardiovaskuler, pernafasan, neuromuskular, gastrointestinal, saluran perkemihan dan kulit.

Salah satu cara untuk menurunkan kecemasan adalah dengan pemberian aromaterapi. Beberapa penelitian menunjukkan bahwa dengan melakukan inhalasi pada aromaterapi mampu menurunkan tingkat kecemasan seseorang. Aromaterapi merupakan tindakan terapeutik dengan menggunakan minyak essensial yang bermanfaat meningkatkan keadaan fisik dan psikologi seseorang agar menjadi lebih baik. Setiap minyak essensial memiliki efek farmakologis yang unik, seperti antibakteri, antivirus, diuretic, vasodilator, penenang dan merangsang adrenal (Runiari, 2016). Kandungan kimia minyak atsiri bunga lavender mengandung komponen linalyl acetate $(40,76 \%)$, linalool $(24,60 \%)$, cis- $\beta$ Ocimene $(4,85 \%), \quad \beta$ caryophyllene $(4,40 \%)$, lavendulyl acetate $(3,83 \%)$, trans $\beta$ Ocimene $(3,64 \%)$, terpinen-4-ol $(3,57 \%), 1.8$ cineole $(0,71)$, lavandulol $(0,71 \%)$, dan camphor (0,30\%) (Lansida, 2017).

Lamadah et al (2016) menyebutkan bahwa inhalasi terhadap minyak essensial dapat meningkatkan kesadaran dan menurunkan kecemasan. Aromaterapi terkenal dengan penggunaannya dalam mengatasi stres. Mc Lain (2016) menjelaskan bahwa aromaterapi lavender dapat memberi rasa tenang, sehingga dapat digunakan sebagai manajemen stres. Kandungan utama dalam minyak lavender adalah linalool asetat yang mampu mengendorkan dan melemaskan sistem kerja urat-urat syaraf dan otot-otot yang tegang. Selain itu, beberapa tetes minyak lavender dapat membantu menanggulangi insomnia, memperbaiki mood seseorang, menurunkan tingkat kecemasan, meningkatkan tingkat kewaspadaan, dan tentunya dapat memberikan efek relaksasi.

Berdasarkan hasil penelitian Syukrini (2016) yang dilakukan kepada 15 ibu persalinan kala I diberikan aroma terapi dengan cara 3 tetes dicampurkan dengan 40ml air dimasukkan ke dalam diffuser dinyalakan selama kurang lebih 15 menit didapatkan nilai signifikan 0,000 yang berarti terdapat perbedaan tingkat kecemasan bermakna antara sebelum dan sesudah diberikan aromaterapi. Bau yang menyenangkan akan menimbulkan perasaan tenang, dan senang yang dapat mengurangi kecemasan. 
Berdasarkan hasil studi pendahuluan yang dilakukan peneliti di RSU Kota Tangerang Selatan pada tanggal 1-7 November 2020 kepada 11 ibu bersalin kala I didapatkan seluruhnya mengalami kecemasan, bahkan 8 ibu mengalami kecemasan berat dan 3 ibu mengalami kecemasan sedang. Menurut informasi dari tenaga kesehatan, selama ini belum pernah memberikan aromaterapi lavender kepada ibu bersalin. Berdasarkan latar belakang tersebut peneliti merasa tertarik untuk melakukan penelitian dengan judul "Pengaruh Aromaterapi Lavender Terhadap Kecemasan Ibu Bersalin di RSU Kota Tangerang Selatan Tahun 2021".

\section{METODOLOGI PENELITIAN}

Penelitian quasi ekspe-rimental ini menggunakan rancangan pretest and posttest with control group design. Sampel dalam penelitian ini berjumlah 30 ibu yang akan melahirkan di RSU Kota Tangerang Selatan dengan masing-masing kelompok 15 responden. Teknik pengambilan sampel menggunakan total sampling. Instrumen penelitian menggunakan kuesioner Hamilton Rating Scale for Anxienty (HRS-A). Pemberian aromaterapi lavender sebanyak 3 tetes dan dicampurkan dengan $40 \mathrm{ml}$ air dimasukkan ke dalam diffuser selanjutnya nyalakan selama kurang lebih 15 menit dan hisap oleh ibu bersalin kala I. Data dianalisis menggunakan $T$-test Independent yang sebelumnya dilakukan uji normalitas dan homogenitas.

\section{HASIL DAN PEMBAHASAN \\ Analisis Deskriptif}

Berdasarkan tabel 1 diketahui bahwa kecemasan ibu bersalin pada kelompok intervensi (kasus) dengan pemberian aromaterapi lavender diperoleh nilai rata-rata pretest $=22,47$ dan nilai rata-rata postest $=18,33$ sehingga didapatkan selisih nilai rata-rata kecemasan ibu bersalin sebelum dan sesudah diberikan aromaterapi lavender sebesar 4,14 . Selanjutnya kecemasan ibu bersalin pada kelompok kontrol pemeriksaan I diperoleh nilai rata-rata pretest $=22,60$ dan nilai rata-rata postest $=22,27$ sehingga didapatkan selisih nilai rata-rata kecemasan ibu bersalin pemeriksaan I dan pemeriksaan pada kelompok kontrol sebesar 0,33 .

Tabel 1

Nilai Rata-Rata Kecemasan Ibu Bersalin Sebelum dan Sesudah Diberikan Aromaterapi Lavender pada Kelompok Intervensi dan Kelompok Kontrol

\begin{tabular}{lcccc}
\hline \multicolumn{1}{c}{ Karateristik } & Mean & Selisih Mean & Min & Max \\
\hline Kelompok Intervensi & & & & \\
Pretest & 22,47 & 4,14 & 20 & 26 \\
Posttest & 18,33 & & 14 & 24 \\
Kelompok Kontrol & & & & \\
Pretest & 22,60 & 0,33 & 20 & 27 \\
Posttest & 22,27 & & 21 & 24 \\
\hline
\end{tabular}

Analisis Analisis Bivariat

Tabel 4.

Perbedaan Kecemasan Ibu Bersalin Sebelum dan Sesudah pada kelompok Intervensi dan Kontrol

\begin{tabular}{|c|c|c|c|c|}
\hline $\begin{array}{l}\text { Kecemasan Ibu } \\
\text { Bersalin }\end{array}$ & $\begin{array}{c}\text { Pretest } \\
\text { Mean }\end{array}$ & $\begin{array}{c}\text { Posttest } \\
\text { Mean }\end{array}$ & $\begin{array}{c}\text { Selisih } \\
\text { Mean }\end{array}$ & $P$ Value \\
\hline Intervensi & 22,47 & 18,33 & 4,14 & 0,000 \\
\hline Kontrol & 22,60 & 22,27 & 0,33 & 0,591 \\
\hline
\end{tabular}

Berdasarkan hasil uji beda menggunakan paired sample t-test memiliki nilai signifikan $0,000<<$ $0,05)$ artinya terdapat perbedaan kecemasan ibu bersalin kelompok intervensi sebelum dan sesudah diberikan aromaterapi lavender di RSU Kota Tangerang Selatan tahun 2021. Sedangkan pada kelompok kontrol hasil uji beda menggunakan paired sample t-test memiliki nilai signifikan 0,591 (> 0,05 ) artinya tidak terdapat perubahan kecemasan ibu bersalin kelompok kontrol pemeriksaan I dan pemeriksaan II di RSU Kota Tangerang Selatan tahun 2021. 
Tabel 5

Pengaruh Aromaterapi Lavender terhadap Kecemasan Ibu Bersalin di RSU Kota Tangerang Selatan

\begin{tabular}{|c|c|c|c|c|}
\hline $\begin{array}{l}\text { Kecemasan Ibu } \\
\text { Bersalin }\end{array}$ & $\begin{array}{c}\text { Intervensi } \\
\text { Mean }\end{array}$ & $\begin{array}{c}\text { Kontrol } \\
\text { Mean } \\
\end{array}$ & $\begin{array}{c}\text { Selisih } \\
\text { Mean }\end{array}$ & $P$ Value \\
\hline Pretest & 22,47 & 22,60 & 0,13 & 0,838 \\
\hline Posttest & 18,33 & 22,27 & 3,94 & 0,001 \\
\hline
\end{tabular}

Hasil uji T-Test Independent diketahui nilai signifikansi sebesar $0,838>0,05$, maka dapat disimpulkan bahwa tidak ada perbedaan kecemasan ibu bersalin sebelum diberikan perlakuan pada kelompok intervensi dan kelompok kontrol pada ibu bersalin di RSU Kota Tangerang Selatan Tahun 2021.

Perhitungan selisih nilai mean (rata-rata) postest kecemasan ibu bersalin pada kelompok intervensi dan kontrol sebesar 3,94. Hasil uji T-Test Independent diketahui nilai signifikansi sebesar $0,001<0,05$, maka dapat disimpulkan bahwa terdapat perbedaan kecemasan ibu bersalin setelah diberikan aromaterapi lavender pada kelompok intervensi pada ibu bersalin di RSU Kota Tangerang Selatan Tahun 2021.

\section{PEMBAHASAN}

Nilai Rata-Rata Kecemasan Ibu Bersalin Sebelum dan Sesudah Diberikan Aromaterapi Lavender pada Kelompok Intervensi

Berdasarkan hasil penelitian pada ibu bersalin pada kelompok intervensi pemberian aromaterapi lavender didapatkan hasil adanya perubahan penurunan kecemasan ibu bersalin dengan nilai rata-rata pretest 22,47 dan nilai ratarata posttest 18,33 sehingga didapatkan selisih nilai rata-rata kecemasan ibu bersalin sebelum dan sesudah diberikan aromaterapi lavender sebesar 4,14. Hal ini menandakan bahwa pemberian aromaterapi lavender baik untuk ibu bersalin.

Dewi (2015) menyatakan bahwa bunga lavender sering dipakai sebagai aromaterapi karena dapat memberikan manfaat relaksasi dan memiliki efek sedasi yang sangat membantu pada orang yang mengalami insomnia. Menurut Tarsikah dalam Susilarini (2017) linalool asetat yang ada pada aromaterapi lavender mampu mengendorkan dan melemaskan sistem kerja urat-urat syaraf dan otototot yang tegang, disamping itu sangat berguna untuk menormalkan keadaan emosi serta keadaan tubuh yang tidak seimbang, dan juga memiliki khasiat sebagai penenang serta tonikum, khususnya pada sistem saraf. Wangi yang dihasilkan aromaterapi lavender akan menstimulasi talamus untuk mengeluarkan enkefalin, berfungsi sebagai penghilang rasa sakit alami. Enkefalin merupakan neuromodulator yang berfungsi untuk menghambat nyeri fisiologi.

Sesuai dengan hasil penelitian Setiati (2019) yang dilakukan kepada 20 ibu hamil trimester III diberikan aroma terapi dengan cara minyak esensial 4-6 tetes dituangkan pada kertas tissue diletakkan di depan hidung dengan jarak $2 \mathrm{~cm}$ selama 3-5 menit. Hasil penelitian ini menunjukkan terjadi penurunan tingkat kecemasan setelah diberikan aromaterapi lavender dibuktikan dengan pemberian aromaterapi lavender lebih efektif 1,52 menurunkan skala kecemasan. Hal ini terjadi karena terapi dengan menggunakan minyak essensial lavender dapat membantu membangkitkan semangat dan menyegarkan. Pemberian aromaterapi lavender efektif menurunkan kecemasan persalinan. Perbedaan penelitian Setiati dengan penelitian ini terdapat pada metode pemberian aromaterapinya.

Begitu juga dengan hasil penelitian Situmorang (2019) mendapatkan hasil bahwa percepatan persalinan kala I pada kelompok intervensi mempunyai nilai rata-rata yaitu 11,60 jam, sedangkan percepatan persalinan kala II pada kelompok intervensi mempunyai nilai rata-rata 64,00 menit, sedangkan pada kelompok kontrol mempunyai nilai rata-rata yaitu 13,73 jam, sedangkan percepatan persalinan kala II pada kelompok kontrol mempunyai nilai rata-rata 84,00 menit. Pemberian aromaterapi lavender bermanfaat meningkatkan kondisi fisik dan psikologis ibu saat bersalin. Secara fisik baik digunakan untuk mengurangi rasa nyeri, sedangkan secara psikologis dapat membuat pikiran menjadi rileks, menurunkan ketegangan dan kecemasan serta memberikan ketenangan pada ibu agar pada saat proses persalinan lbu mempunyai tenaga untuk mengedan. Adanya bau dari aromaterapi lavender akan merangsang otak untuk mengurangi rasa sakit sehingga dengan mencium lavender maka akan membantu membuat rasa rileks.

Peneliti berasumsi terjadinya penurunan kecemasan pada ibu hamil yang mendapatkan aromaterapi lavender, hal ini disebabkan oleh karena dalam minyak lavender terdapat kandungan linelol asetat dimana kandungan tersebut dihirup masuk ke hidung yang selanjutnya ditangkap oleh 


\section{JKM (Jurnal Kebidanan Malahayati),Vol 7,No.4.Oktober 2021, \\ ISSN (Print) 2476-8944 ISSN (Online) 2579-762X, Hal 785-792}

saraf yang akhirnya akan masuk ke otak, disinilah otak bekerja dimana sebagai tempat pusat memori suasana hati dan intelektualitas berada. Adanya bau yang menyenangkan menciptakan rasa tenang dan senang sehingga dapat mengurangi kecemasan. Wangi yang dihasilkan oleh aromaterapi lavender akan merangsang thalamus untuk mengeluarkan enkefalin dimana enkefalin tersebut merangsang otak untuk mengeluarkan serotonin sehingga menimbulkan efek rileks, tenang dan mengurangi rasa nyeri yang pada akhirnya menurunkan kecemasan.

Sesuai dengan hasil observasi pada kecemasan lbu ditemukan sebelum mendapatkan aromaterapi lavender banyak ibu yang mengalami susah untuk konsentrasi, merasa sedih dan suka bangun dini hari, adanya perasaan berubah-rubah, sakit dan nyeri pada otot, kaku, adanya perasaan lemas dan muka terlihat pucat terkadang terlihat memerah, denyut jantung berdetak cepat, dilihat dari segi pernapasan sering menarik nafas panjang, terkadang juga menarik nafas secara pendek, ada perasaan mual kembung, sering kencing, pusing, sakit kepala, kepala terasa berat, gelisah, dan muka terlihat tegang. Setelah mendapatkan aromaterapi lavender ternyata ibu terlihat menjadi rileks dimana pada saat ditanya Ibu bisa menjawab, perasaan sakit kepala mulai berkurang, bahkan ibu merasakan sakit saat kontraksi bisa dikontrol. Hal ini menandakan bahwa aromaterapi dapat menciptakan rasa tenang dan rileks sehingga dapat mengurangi kecemasan.

\section{Nilai Rata-Rata Kecemasan lbu Bersalin Sebelum dan Sesudah Diberikan Aromaterapi Lavender pada Kelompok Kontrol}

Berdasarkan hasil penelitian pada ibu bersalin pada kelompok kontrol didapatkan hasil adanya perubahan penurunan kecemasan ibu bersalin kelompok kontrol dengan nilai rata-rata pretest 22,60 dan nilai rata-rata posttest 22,27 sehingga didapatkan selisih nilai rata-rata kecemasan ibu bersalin pemeriksaan I dan pemeriksaan pada kelompok kontrol sebesar 0,33.

Rohani (2017) menjelaskan bahwa ibu yang mengalami persalinan akan mengalami kekuatan kontraksi uterus yang muncul diawali dengan kekuatan kecil kemudian terus meningkat sampai puncaknya yaitu pembukaan serviks yang sudah lengkap, kondisi ini dapat menimbulkan terjadinya suatu kecamatan.

Suliswati (2015) mengemukakan bahwa teori terjadinya kecemasan sesuatu dorongan yang dipelajari berdasarkan keinginan untuk menghindari rasa sakit pada individu yang pada awal kehidupan dihadapkan pada rasa takut yang berlebihan akan menunjukkan kemungkinan kecemasan yang berat pada kehidupan masa dewasanya.

Simpkin (2015) berpendapat bahwa faktor psikologis yang berhubungan dengan kecemasan selama persalinan kala I yaitu beberapa ketakutan melahirkan. Takut akan peningkatan nyeri, takut akan kerusakan atau kelainan bentuk tubuhnya seperti episiotomi, rupture, jahitan ataupun seksio sesarea, serta ibu takut akan melukai bayinya. Faktor psikis dalam persalinan merupakan faktor yang sangat penting mempengaruhi lancar tidaknya proses kelahiran. Menurut Semiun (2014), dampak kecemasan terbagi ke dalam beberapa simptom, antara lain gejala suasana hati seperti susah tidur dan dan mudah marah, simtom kognitif karena adanya kekhawatiran dan keprihatinan sehingga hilang konsentrasi dan Sintong motorik gimana ada perasaan tidak tenang guguk dan kaget secara tibatiba.

Sesuai dengan hasil penelitian Salamah (2019) ditemukan hasil kecemasan pada kelompok kontrol sebelum dan sesudah tidak ditemukan adanya perbedaan. Hal ini disebabkan oleh adanya faktor psikologis dan adanya ketakutan proses persalinannya tidak lancar, disamping itu disebabkan adanya pengalaman di masa lalu sehingga menimbulkan perasaan cemas yang berlebihan. Penelitian selanjutnya oleh Haslin (2018) ditemukan pada kelompok kontrol sebelum periode intervensi didapatkan mayoritas intensitas nyeri sedang yaitu 6 orang $(40 \%)$, dan setelah periode intervensi didapatkan mayoritas kategori intensitas nyeri berat terkontrol yaitu 12 orang $(80 \%)$. Hal ini menandakan intensitas nyeri semakin meningkat. Hal ini disebabkan oleh karena pada primipara mengalami persalinan yang lebih panjang sehingga mereka merasa letih. Hal ini menyebabkan peningkatan nyeri. Rasa nyeri yang terjadi selama kala I juga disebabkan oleh kontraksi uterus yang terus meningkat untuk mencapai pembukaan servik yang lengkap. Semakin bertambahnya volume dan frekuensi kontraksi uterus maka rasa nyeri juga akan semakin meningkat.

Peneliti berasumsi terjadinya kecemasan pada ibu bersalin dengan kelompok kontrol tidak mengalami perubahan disebabkan oleh karena ibu bersalin mengalami proses kontraksi uterus yang terus meningkat untuk mencapai pembukaan serviks, hal ini menimbulkan adanya kecemasan yang meningkat yang disebabkan oleh adanya rasa sakit yang semakin kuat sehingga menimbulkan perasaan putus asa, bahkan tidak sanggup menahan sakit yang diderita. Hal inilah yang 
menimbulkan terjadinya kecemasan pada ibu bersalin. Faktor penyebab terjadinya kecemasan disebabkan oleh karena adanya ketakutan yang berlebihan, kurangnya dukungan dari keluarga juga dapat memperparah rasa sakit yang diderita oleh ibu sehingga dapat menimbulkan rasa tidak tenang, gugup dan menimbulkan kecemasan yang berlebihan. ibu pada masa persalinan kala I fase laten pada umumnya ingin berbicara, perlu ditemani, tidak tidur, ingin berjalan-jalan dan menciptakan kontak mata. Sedangkan pada ibu pada masa persalinan kala I fase aktif menjadi lebih serius dan ibu menginginkan seseorang untuk mendampinginya karena rasa takut akan ketidakmampuannya beradaptasi dengan kontraksi. Kehadiran suami atau keluarga dalam kamar bersalin akan membawa ketentraman bagi ibu yang akan melahirkan, suami juga dapat memainkan peranan aktif dalam memberi dukungan fisik dan dorongan mental kepada istrinya

\section{Pengaruh Aromaterapi Lavender terhadap Kecemasan Ibu Bersalin}

Hasil selisih nilai rata-rata kecemasan ibu bersalin posttest antara kelompok intervensi (pemberian aromaterapi lavender) dengan kelompok kontrol didapatkan bahwa kelompok intervensi mengalami penurunan kecemasan ibu bersalin lebih banyak dibandingkan pada kelompok kontrol yaitu 4,14 pada kelompok intervensi dan 0,33 pada kelompok kontrol. Perhitungan selisih nilai mean (rata-rata) postes kecemasan ibu bersalin pada kelompok intervensi dan kontrol sebesar 3,94. Hasil uji T-Test Independent diketahui nilai signifikansi sebesar 0,001 >0,05, maka dapat disimpulkan bahwa ada perbedaan kecemasan ibu bersalin setelah diberikan perlakuan pada kelompok intervensi dan kelompok kontrol pada ibu bersalin di RSU Kota Tangerang Selatan Tahun 2021.

Menurut Aryasatiani (2017) terdapat beberapa penentu terjadinya kecemasan pada ibu bersalin yaitu, nyeri persalinan, pengalaman masa lalu, keadaan fisik ibu, riwayat pemeriksaan kehamilan, kurangnya pengetahuan tentang proses persalinan, dukungan dari lingkungan sosial serta latar belakang psikososial lain dari ibu yang bersangkutan, seperti tingkat pendidikan, status perkawinan, kehamilan yang tidak diinginkan, dan sosial ekonomi. Notoatmodjo (2018) menambahkan bahwa salah satu faktor yang berhubungan dengan gangguan kecemasan pada kala I adalah pengetahuan. Berdasarkan pengalaman dan penelitian, perilaku cemas didasarkan salah satunya pada pengetahuan seorang ibu. Dimana seorang ibu mengalami kecemasan pada saat ibu tidak memiliki pengetahuan tentang persalinan dan bagaimana prosesnya.

Mclain (2016) menjelaskan bahwa minyak lavender bisa menjadi obat yang efektif dalam pengobatan beberapa gangguan neurologis. Yamada, et al (2015) menjelaskan bahwa minyak lavender adalah salah satu aromaterapi yang terkenal memiliki efek sedatif, hypnotic dan antineurodepresive pada manusia. Karena minyak lavender dapat memberi rasa tenang, sehingga dapat digunakan sebagai manajemen stres. Kandungan utama dalam minyak lavender adalah linalool asetat yang mampu mengendorkan dan melemaskan sistem kerja urat-urat syaraf dan otototot yang tegang. Ester sangat berguna untuk menormalkan keadaan emosi serta keadaan tubuh yang tidak seimbang, dan juga memiliki khasiat sebagai penenang serta tonikum, khususnya pada sistem saraf. Wangi yang dihasilkan aromaterapi lavender akan menstimulasi talamus untu mengeluarkan enkefalin, berfungsi sebagai penghilang rasa sakit alami. Enkefalin merupakan neuromodulator yang berfungsi untuk menghambat nyeri fisiologi.

Dewi (2015) berpendapat bahwa beberapa tetes minyak lavender dapat membantu menanggulangi insomnia, memperbaiki mood seseorang, menurunkan tingkat kecemasan, meningkatkan tingkat kewaspadaan, dan tentunya dapat memberikan efek relaksasi. Yamada, et al (2015) menambahkan bahwa minyak lavender adalah salah satu aromaterapi yang terkenal memiliki efek menenangkan. Penelitian yang dilakukan terhadap manusia mengenai efek aromaterapi lavender untuk relaksasi, kecemasan, mood, dan kewaspadaan pada aktivitas EEG (Electro Enchepalo Gram) menunjukkan terjadinya penurunan kecemasan, perbaikan mood dan terjadi peningkatan kekuatan gelombang alpha dan beta pada EEG yang menunjukkan peningkatan relaksasi. Didapatkan pula hasil yaitu terjadi peningkatan secara signifikan dari kekuatan gelombang alpha di daerah frontal, yang menunjukkan terjadinya peningkatan rasa kantuk.

Syukrini (2016) yang dilakukan kepada 15 ibu persalinan kala I diberikan aroma terapi dengan cara 3 tetes dicampurkan dengan $40 \mathrm{ml}$ air dimasukkan ke dalam diffuser dinyalakan selama kurang lebih 15 menit didapatkan hasil $p=0,000$ $<0,05$ dimana rata-rata skor kecemasan dengan pemberian aromaterapi lebih kecil daripada yang tidak yang berarti kelompok intervensi mengalami penurunan tingkat kecemasan yang lebih baik daripada kelompok kontrol. Hal ini disebabkan aromaterapi dapat mempengaruhi aktivitas fungsi 


\section{JKM (Jurnal Kebidanan Malahayati),Vol 7,No.4.Oktober 2021, \\ ISSN (Print) 2476-8944 ISSN (Online) 2579-762X, Hal 785-792}

kerja otak melalui sistem saraf dan dapat meningkatkan produksi masa penghantar saraf otak yang dapat memulihkan kondisi psikis seperti emosi, perasaan, pikiran dan keinginan, selain itu aromaterapi juga dapat memberikan efek relaksasi bagi saraf dan otot-otot yang tegang.

Balqis (2018) yang dilakukan kepada $30 \mathrm{ibu}$ persalinan kala I fase aktif diberikan aromaterapi lavender dengan cara inhalasi yaitu aromaterapi lavender sebanyak $0,1 \mathrm{ml}$ diencerkan dengan minyak karieziatun (virgin olive oil) sebanyak $1 \mathrm{ml}$. teteskan 3 tetes essensial oil lavender yang telah diencerkan pada tisu ukuran $15 \mathrm{~cm} \times 15 \mathrm{~cm}$ dihirup mengikuti tarikan nafas selama 5 menit. Penelitian ini sebelum diberikan aromaterapi lavender pada kecemasan sedang $60 \%$ dan setelah diberikan aromaterapi lavender rata-rata tingkat kecemasan ibu pada kecemasan sedang 56,7\%. Hasil ini menunjukkan adanya penurunanan tingkat kecemasan ibu bersalin setelah diberikan aromaterapi lavender. Hasil uji statistik didapatkan $p$-value : $0,000<\alpha: 0,05$. Sehingga, ada pengaruh pemberian aromaterapi lavender dalam menurunkan kecemasan ibu bersalin.

Penelitian selanjutnya dilakukan Setiati (2019) yang dilakukan kepada 20 ibu hamil trimester III diberikan aroma terapi dengan cara minyak esensial 4-6 tetes dituangkan pada kertas tissue diletakkan di depan hidung dengan jarak 2 $\mathrm{cm}$ selama 3-5 menit. Hasil penelitian ini menunjukkan terjadi penurunan tingkat kecemasan setelah diberikan aromaterapi lavender dibuktikan dengan pemberian aromaterapi lavender lebih efektif 1,52 menurunkan skala kecemasan dibandingkan dengan tanpa memberikan aromaterapi pada ibu hamil trimester III yang diperoleh dari rata-rata skala kecemasan pada kelompok intervensi sebesar, 6,31 dan rata-rata skala kecemasan pada kelompok kontrol sebesar 4,16 sehingga terdapat selisih efektif sebesar 1,52, sehingga hasil penelitian mengenai kecemasan ibu hamil trimester III yang diberikan aromaterapi lavender menjadi objektif dan datanya tidak bias.

Peneliti berasumsi adanya pengaruh aromaterapi lavender terhadap kecemasan ibu bersalin disebabkan oleh karena dimulai adanya proses penguapan dari aromaterapi tersebut yang selanjutnya di hisap oleh ibu bersalin dan diserap oleh tubuh melalui hidung dan paru-paru masuk ke aliran darah. Saat aroma dari minyak esensial lavender dihirup, tubuh akan memberikan respon psikologis dimana tubuh menjadi nyaman rasa sakit dan ketegangan berkurang, serta kecemasan dalam menghadapi persalinan juga berkurang. Adanya proses penurunan kecemasan yang berbeda-beda pada kelompok pada ibu bersalin dipengaruhi oleh perasaan yang dimiliki oleh ibu sendiri seperti adanya persepsi cemas, adanya reaksi ketakutan, kegelisahan, dirasakan oleh ibu sendiri. Alangkah baiknya selain dengan memberikan aromaterapi lavender juga memberikan dukungan pada ibu bersalin agar kecemasan Ibu menurun, disamping itu adanya pendekatan dari tenaga kesehatan dalam memberikan pelayanan juga dapat mengurangi rasa cemas yang dialami oleh ibu bersalin.

\section{SIMPULAN}

Berdasarkan hasil penelitian dapat disimpulkan bahwa terjadi penurunan rata-rata tingkat kecemasan ibu bersalin sesudah diberikan aromaterapi lavender. Terdapat pengaruh aromaterapi lavender terhadap kecemasan ibu bersalin di RSU Kota Tangerang Selatan Tahun 2021.

\section{SARAN}

Diharapkan pemberian aromaterapi lavender dapat dijadikan sebagai pertimbangan untuk terapi komplementer bagi bidan dan tenaga kesehatan lainnya yang berada dipelayanan baik rumah sakit maupun tempat bersalin sebagai upaya untuk mengurangi kecemasan pada ibu bersalin.

\section{DAFTAR PUSTAKA}

Aryasatiani. (2017). Menjaga Wanita Takut Menghadapi Persalinan Normal. Jakarta: Penebar Swadaya.

Balqis, K.P. (2018). Pengaruh Aromaterapi Lavender Terhadap Tingkat Kecemasan Ibu Bersalin Di BPM Kota Palembang. Skripsi. Poltekkes Kemenkes Palembang

Dewi, IGA. (2015). Aromaterapi Lavender Sebagai Media Relaksasi. Farmasi Fakultas Kedokteran Universitas Udayana. Jurnal Kesehatan. Volume 2 Nomor 1. Hal. 21-53.

Haslin, S. (2018). Pengaruh Aromaterapi Lavender Terhadap Penurunan Intensitas Nyeri pada Persalinan Primigravida Kala I Fase Aktif di Klinik Pratama Tanjung Kec. Deli Tua. Skripsi. Politeknik Kesehatan Kemenkes Ri Medan.

Jaelani. (2017). Aromaterapi. Jakarta: Pustaka Populer Obor.

Kasdu, D. (2015). Solusi Problem Persalinan. Jakarta: Puspa Swara.

Lamadah, S.M., Nomani, Ibtesam. (2016). The Effect of Aromatherapy Massage Using Lavender Oil on the Level of Pain and Anxiety During Labour Among Primigravida 
Women. American Journal of Nursing Science Volume 5 Nomor 2: Hal. 37-44.

McLain DE. (2016). Chronic Health Effects Assessment of Spike Lavender Oil. Walker Doney and Associates.

Nolan, M. (2018). Kehamilan \& Melahirkan. Jakarta: Arcan.

Notoatmodjo, S. (2018). Promosi Kesehatan dan Perilaku. Jakarta: Rineka Cipta

Rohani. (2017). Asuhan Kebidanan pada Masa Persalinan. Jakarta: Salemba Medika.

Salamah, N. (2019). Pengaruh Aromaterapi Lavender Terhadap Tingkat Kecemasan Ibu Hamil Timester III di Wilayah Kerja Puskesmas Seyegan. Naskah Publikasi. Universitas Aisyiyah Yogyakarta.

Semiun, Y. (2017). Kesehatan Mental. Yogyakarta: Kanisius.

Setiati, N.W., Sugih, S., Wijayanegara, H. (2019). Efektivitas Pemberian Aromaterapi Lavender Untuk Menurunkan Kecemasan Ibu Hamil Trimester III dalam Persiapan Menghadapi Persalinan di Bidan Praktek Mandiri Nurussyifa Kecamatan Buniseuri Ciamis. Jurnal Kesehatan Bakti Tunas Husada: Jurnal IImu IImu Keperawatan, Analis Kesehatan dan Farmasi. Volume 19 Nomor 1.

Simpkin, P. (2015). Buku Saku Persalinan. Jakarta: EGC.
Stuart. (2016). Buku Saku Keperawatan Jiwa. Jakarta: EGC.

Suliswati. (2015). Konsep Dasar Keperawatan Jiwa. Jakarta: EGC.

Susilarini. (2017). Pengaruh Pemberian Aromatherapi Lavender Terhadap Pengendalian Nyeri Persalinan Kala I Pada Ibu Bersalin. Jurnal Kebidanan. Volume 6, Nomor 12. Hal. 47-54.

Syukrini, R.D. (2016). Pengaruh Aromaterapi Terhadap Tingkat Kecemasan pada lbu Persalinan Kala I di Kamar Bersalin RSU Kab. Tangerang. Skripsi. Universitas Islam Negeri Syarif Hidayatullah Jakarta.

WHO. (2019). Neonatal and Perinatal Mortality : Country, Regional and Global Estimates. In: Organization WH, editor. Geneva: World Health Organization.

Yamada K, Mimaki Y, Sashida Y, (2015). Effect Inhaling of the Vapor of Lavandula burnatii super-Derrived Esensial Oil and Linalool on Plasma Adrenocorticotropin Hormone (ACTH), Catecholamine and Gonadotropin Level in Experimental Menopausal Female Rats. Pharmaceutical Society of Japan. Volume 28 Nomor 2. Hal. 1-18.

Yosep, I. (2017). Keperawatan Jiwa. Bandung: PT Refika Aditama 